\title{
Enterocolitis and Colon Cancer in Interleukin-10-deficient Mice Are Associated with Aberrant Cytokine Production and CD4 ${ }^{+}$TH1-like Responses
}

\author{
Daniel J. Berg, ${ }^{\star}$ Natalie Davidson, ${ }^{\star}$ Ralf Kühn, ${ }^{\ddagger}$ Werner Müller, ${ }^{\ddagger}$ Satish Menon, ${ }^{\S}$ Gina Holland, ${ }^{*}$ LuAnn Thompson-Snipes, ${ }^{\star}$ \\ Michael W. Leach, and Donna Rennick* \\ $*$ Department of Immunology and ${ }^{\S}$ Molecular Biology, DNAX Research Institute of Cellular and Molecular Biology, Palo Alto, California \\ 94304; "Schering Plough Research Institute, Lafayette, New Jersey 07848; and ${ }^{\ddagger}$ Institute for Genetics, University of Cologne, 50931 \\ Cologne, Federal Republic of Germany
}

\begin{abstract}
We have characterized the progressive stages of chronic intestinal inflammation that develops spontaneously in specific pathogen-free (SPF) mice with a targeted disruption in the IL-10 gene (IL-10 ${ }^{-I-}$ ). Our longitudinal studies showed that inflammatory changes first appear in the cecum, ascending and transverse colon of 3-wk-old mutants. As the disease progressed, lesions appeared in the remainder of the colon and in the rectum. Some aged $\mathrm{IL}-10^{-1-}$ mice also developed inflammation in the small intestine. Prolonged disease with transmural lesions and a high incidence of colorectal adenocarcinomas $(60 \%)$ was observed in 6-mo-old mutants. Mechanistic studies have associated uncontrolled cytokine production by activated macrophages and $\mathrm{CD}^{+}$ Th1-like $\mathrm{T}$ cells with the enterocolitis exhibited by $\mathrm{IL}-10^{-1-}$ mice. A major role for a pathogenic Th1 response was further suggested by showing that anti-IFN $\gamma$ antibody (Ab) treatment significantly attenuated intestinal inflammation in young $\mathrm{IL}-10^{-1-}$ mice. When weanlings were treated with IL-10, they failed to develop any signs of intestinal inflammation. Interestingly, IL-10 treatment of adults was not curative but did ameliorate disease progression. Our studies have also shown that inheritable factors strongly influence the disease susceptibility of IL-10 ${ }^{-1-}$ mice. In 3-mo-old mutants, intestinal lesions were most severe in $\mathrm{IL}_{-10}{ }^{-/-} 129 /$ SvEv and IL-10 ${ }^{-l-}$ BALB/c strains, of intermediate severity in the IL-10 ${ }^{-1-} 129 \times \mathrm{C} 57 \mathrm{BL} / 6 \mathrm{~J}$ outbreds, and least severe in the IL-10 ${ }^{-1-}$ C57BL/6J strain. (J. Clin. Invest. 1996. 98: 1010-1020.) Key words: inflammatory bowel disease, colitis, IFN $\gamma \cdot$ adenocarcinoma $\cdot$ IL-10 therapy - genetic susceptibility
\end{abstract}

\section{Introduction}

We have reported that outbred mice with a targeted disruption in the IL-10 gene (IL-10 $\left.0^{-/-}\right)^{1}$ spontaneously develop a generalized enterocolitis under conventional housing conditions (1). When IL- $10^{-/-}$mice were derived and maintained under spe-

Address correspondence to Donna Rennick, Ph.D., DNAX Research Institute, 901 California Ave., Palo Alto, CA 94304. Phone: 415-4961154; FAX: 415-496-1200.

Received for publication 24 October 1995 and accepted in revised form 11 June 1996.

J. Clin. Invest.

(c) The American Society for Clinical Investigation, Inc.

0021-9738/96/08/1010/11 \$2.00

Volume 98, Number 4, August 1996, 1010-1020 cific pathogen-free (SPF) conditions, intestinal inflammation was less severe and occurred only in the mucosa of the proximal colon (1). The diminished form of disease observed in SPF IL-10 $0^{-1-}$ mice suggested that an uncontrolled immune response to normal gut flora may play a causal role. In vitro studies have shown that IL-10 can be produced by a variety of cell types and that it possesses both stimulatory and inhibitory activities (reviewed in reference 2). It has been hypothesized (1) that the intestinal disease in IL- $10^{-1-}$ mice is due to the absence of the general suppressive effects of IL-10 on cytokine production by macrophages $(3,4)$ and Th1 T cells $(5)$. This hypothesis fits well with studies showing that IL-10 $10^{-1-}$ mice are prone to developing exaggerated (pathogenic) immune responses when challenged with Th1 T cell-dependent or macrophage-dependent antigens. Hence, they are abnormally sensitivity to LPS (6) and to skin irritants including those that elicit contact hypersensitivity reactions (7).

Recently, it has been discovered that rodents with different types of gene-targeted disruptions spontaneously develop colitis. These include transgenic mice lacking the $\mathrm{T}$ cell receptor (TcR) $\alpha$ chain, TcR $\beta$ chain, TcR $\delta \times \beta$ chains (8), G protein subunit $\alpha_{\mathrm{i} 2}\left(\mathrm{G}_{\mathrm{i} 2}\right)$ (9), TGF- $\beta$ (10), and IL-2 (11). As in the case of IL-10 $10^{-1-}$ mice, disease was ameliorated or absent in mutants $(8,11)$ raised under specific pathogen-free or germfree conditions, respectively. Colitis can also be induced in $\mathrm{Tg}$ $\epsilon 26$ mice reconstituted with bone marrow (12) and in scid mice reconstituted with $\mathrm{CD}^{+}{ }^{+} \mathrm{CD} 45 \mathrm{RB}^{\text {hi }} \mathrm{T}$ cells $(13,14)$. Collectively, these results demonstrate that any number of alterations affecting immunoreactive cells can disrupt the delicate balance between a protective and a pathogenic response to ordinary intestinal flora.

Chronic inflammatory bowel diseases (IBD) in humans comprise complex disorders that have been conveniently divided into two major forms, ulcerative colitis (UC) and Crohn's disease (CD) $(15,16)$. Although the etiology of IBD in humans remains unknown, most evidence implicates an immunopathologic response (17-20), perhaps to intestinal flora (21). Preliminary studies have indicated that transgenic rodents (1, 8-11) and transplanted immunodeficient mice (12-14) develop phenotypically distinct diseases that resemble either UC or CD. Therefore, these animals are considered excellent models for identifying the complex mechanisms involved in initiating and perpetuating different types of human IBD.

1. Abbreviations used in this paper: $\mathrm{Ab}$, antibody; $\mathrm{CD}$, Crohn's disease; $\mathrm{H} \& \mathrm{E}$, hematoxylin and eosin; IBD, inflammatory bowel disease; IEL, intraepithelial lymphocytes; IL-10 ${ }^{-/-}$, homozygous for the IL-10 gene with a targeted disruption; LPL, lamina propria lymphocytes; TcR, T cell receptor; Th1, T helper cell, type 1; UC, ulcerative colitis; wt, wild type. 
Herein, we have characterized the intestinal disorder present in IL-10 $10^{-1-}$ mice including specific features of progressive disease in aging mice and the influence of genetic backgrounds on disease severity. The results of immunohistologic and cytokine analyses have linked enterocolitis in IL-10-1mice to the uncontrolled production of pro inflammatory mediators by macrophages and Th1-like $\mathrm{T}$ cells. The possibility of preventing or ameliorating disease by treating IL- $10^{-1-}$ mice with anti-IFN $\gamma \mathrm{Ab}$ or IL-10 was also investigated.

\section{Methods}

Animals. IL-10 ${ }^{-1-}$ mice generated on a C57BL/6/129-Ola background (1) and wild-type (wt) littermate controls were derived by cesarean section under specific-pathogen free conditions at Simonsen Laboratory (Gilroy, CA) and maintained in micro isolator cages in the animal care facility at DNAX (Palo Alto, CA). IL- $10^{-1-}$, wt, and sentinel mice were periodically examined by the Research Animal Diagnostic and Investigative Laboratory (University of Missouri, Columbia, MO). Bacterial cultures, parasitological examinations, serologic tests and special histological stains were negative for known murine viral and bacterial pathogens. Therefore, the IL- $10^{-/-}$and wt mice used in our studies are considered to be reared under "clean" rather than "conventional" conditions.

Unless otherwise specified, all studies were performed with "clean" chimeric IL-10 $10^{-1-}$ mice $(\mathrm{C} 57 \mathrm{BL} / \mathrm{B} 6 \times 12901 \mathrm{l})(1)$. Other experiments were conducted with "clean" IL- $10^{-1-}$ mice where the mutated IL-10 gene was selectively bred onto C57BL/6J, BALB/c or 129/ SvEv backgrounds. Normal C57BL/6J, and BALB/c were obtained from Jackson Laboratories (Bar Harbor, ME) and 129/SvEv mice were obtained from Taconic (Germantown, NY).

Reagents. LPS from Escherichia coli (serotype 0111:B4) was obtained from DIFCO (Detroit, MI) and resuspended in pyrogen-free saline. Recombinant murine IL-10 was expressed in E. coli as inclusion bodies and purified after renaturation to homogeneity using hydrophobic and ion exchange chromatography. The protein concentration in the purified preparations was determined by the extinction coefficient of the protein $(1 \mathrm{mg} / \mathrm{ml}=0.36$ A280). This material contained $<0.10$ endotoxin units (EU) per $\mathrm{mg}$ of protein, and remained stable at $4^{\circ} \mathrm{C}$ for at least 6 mo. The specific activity of murine IL-10 $\left(\sim 1.0 \times 10^{7} \mathrm{U} / \mathrm{mg}\right)$ was determined in a proliferation assay using $\mathrm{Ba} /$ F3 cells expressing the IL-10 receptor (22).

Histologic analysis. Tissues from wt and IL- $10^{-/-}$mice were fixed in $10 \%$ neutral buffered formalin, routinely processed, sectioned at $6 \mu \mathrm{m}$, and stained with hematoxylin and eosin (H \& E) for light microscopic examination. Samples from lung, heart, liver, kidney, spleen, mesenteric lymph nodes, and the entire gastrointestinal tract were examined by the same pathologist. Because intestinal lesions were multifocal and of variable severity, the grades given to any section of intestine took into account the number of lesions as well as their severity. A score from 0 to 4 was based on the following criteria: (grade 0) no change from normal tissue; (grade 1) one or a few multifocal mononuclear cell infiltrates in the lamina propria accompanied by minimal epithelial hyperplasia and slight to no depletion of mucus from goblet cells; (grade 2) lesions tended to involve more of the intestine than grade 1 lesions, or were more frequent. Typical changes included several multifocal, mild inflammatory cell infiltrates in the lamina propria composed primarily of mononuclear cells with a few neutrophils. Mild epithelial hyperplasia and mucin depletion were also seen. Small epithelial erosions were occasionally present and inflammation rarely involved the submucosa; (grade 3) lesions involved a large area of the mucosa or were more frequent than grade 2 lesions. Inflammation was moderate and often involved the submucosa but was rarely transmural. Inflammatory cells were a mixture of mononuclear cells as well as neutrophils, and crypt abscesses were sometimes observed. Moderate epithelial hyperplasia and mucin depletion were seen. Ulcers were occasionally observed; (grade 4) le- sions usually involved most of the intestinal section and were more severe than grade 3 lesions. Inflammation was severe, including mononuclear cells and neutrophils, and was sometimes transmural. Epithelial hyperplasia was marked with crowding of epithelial cells in elongated glands. Few mucin-containing cells were seen. Crypt abscesses and ulcers were present.

Each segment of the colon (cecum, ascending, transverse, and descending colon and rectum) was given a score based on the criteria described above and the summation of these scores provided a total colonic disease score per mouse. The disease scores could range from 0 (no change in any segment) to a maximum of 20 (grade 4 lesions in all five segments). The small intestine was graded in a similar manner.

Ab used for flow cytometry and cell sorting. All Tri-Color ${ }^{\mathrm{TM}} \mathrm{mAb}$ were diluted in $1 \%(\mathrm{vol} / \mathrm{vol}) \mathrm{FCS}$ in PBS. The reagents used were: Tri-Color ${ }^{\mathrm{TM}}$-conjugated rat anti-mouse CD4 (clone L3/T4; $6 \mu \mathrm{g} / \mathrm{ml}$; Caltag, South San Francisco, CA); phycoerythrin-conjugated rat anti-mouse CD8 $\alpha$ (clone 53-6.7; $4 \mu \mathrm{g} / \mathrm{ml}$; Pharmingen, San Diego, CA); biotin-conjugated rat anti-mouse CD $8 \beta$ (clone 53-5.8; $5 \mu \mathrm{g} / \mathrm{ml}$; Pharmingen); FITC-conjugated CD4 $(5 \mu \mathrm{g} / \mathrm{ml}$; Pharmingen); Tri-

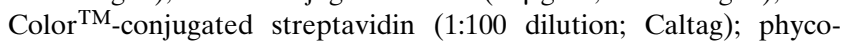
erythrin-conjugated hamster anti-mouse $\alpha \beta$ TCR (clone H57-597; $1 \mu \mathrm{g} / \mathrm{ml}$; Pharmingen); FITC-conjugated hamster anti-mouse $\gamma \delta$ TCR (clone GL3; $5 \mu \mathrm{g} / \mathrm{ml}$; Pharmingen); FITC-conjugated rat anti-mouse CD45RB (clone 16A; $5 \mu \mathrm{g} / \mathrm{ml}$; Pharmingen), CD44 (clone IM7; $1 \mu \mathrm{g} /$ $\mathrm{ml}$; Pharmingen), CD69 (clone H1.2F3; $10 \mu \mathrm{g} / \mathrm{ml}$; Pharmingen), and CD62L (clone Mel-14; $10 \mu \mathrm{g} / \mathrm{ml}$; Pharmingen).

$A b$ used for section staining. All $\mathrm{mAb}$ were diluted in $1 \%$ (vol/ vol) FCS in PBS. The reagents used were: purified rat anti-mouse CD4 (clone L3/T4; $4 \mu \mathrm{g} / \mathrm{ml}$; Caltag); purified rat anti-mouse CD8 $\alpha$ (clone 53.67; $4 \mu \mathrm{g} / \mathrm{ml}$; Pharmingen); rat anti-mouse F4/80 tissue culture supernatant (clone A3-1; 1:50 dilution; BMA, Westbury, NY); rat anti-mouse MTS6 (anti-I-A, I-E) kindly provided by Dr. R.L. Boyd (Monash University, Melbourne, Australia); and rabbit antibovine cytokeratin (broad-spectrum anti-sera; 1:100 dilution; Dakopatts, Santa Barbara, CA). Second stage Ab were goat anti-rat IgG $(\gamma+\mathrm{L})$-FITC $(8 \mu \mathrm{g} / \mathrm{ml}$; Caltag) and rhodamine isothiocyanate-conjugated goat anti-rabbit IgM and $\operatorname{IgG}(\mathrm{H}+\mathrm{L})(25 \mu \mathrm{g} / \mathrm{ml}$; Southern Biotechnology Associates Inc., Birmingham, AL).

Preparation of colon intraepithelial and lamina propria lymphocytes. Gut lymphocytes were isolated from IL-10 ${ }^{-1-}$ or wt mice according to a modified protocol of Lefrançois (23). Intestinal tissue was trimmed of fat and connective tissue and Peyer's patches were removed. The intestinal tissue was washed extensively in PBS, chopped and then incubated in $2 \mathrm{mM}$ EDTA in PBS for $30 \mathrm{~min}$ at $37^{\circ} \mathrm{C}$ with stirring to release intraepithelial lymphocytes (IEL). Lamina propria lymphocytes (LPL) were isolated from the remaining tissue fragments by incubation in $0.2 \mathrm{mg} / \mathrm{mL}$ collagenase/dispase (Boehringer Mannheim, Indianapolis, IN) for $30 \mathrm{~min}$ at $37^{\circ} \mathrm{C}$ with stirring. The IEL and LPL preparations were then washed and sieved twice through nylon gauze (pore size $100 \mu \mathrm{m}$ ) and twice through 70- $\mu \mathrm{m}$ Falcon cell filters (Becton Dickinson, Franklin Lakes, NJ). Lymphocytes were enriched by centrifugation within $40 \%$ (vol/vol) Percoll (Pharmacia LKB, Uppsala, Sweden) overlaid on $75 \%$ Percoll for $20 \mathrm{~min}$ at $750 \mathrm{~g}$.

Before cell sorting, T cells were enriched by depletion of B cells, neutrophils and macrophages. Cell preparations were incubated with anti-B220, -8C5 and -Mac $1 \mathrm{Ab}$ and the Ab-reactive cells were removed in a magnetic field using a combination of goat anti-rat $\mathrm{IgG}$ $(\mathrm{Fc})$ and goat anti-rat $\operatorname{IgG}(\mathrm{H}+\mathrm{L})$ coated magnetic beads (Advanced Magnetics, Cambridge, MA). The remaining cells were stained with CD4-FITC and CD8 $\alpha$-PE for $20 \mathrm{~min}$ on ice. Flow cytometric analysis was performed using a FACScan ${ }^{\circledR}$ (Becton Dickinson, Sunnyvale, CA) and data were analyzed using the CellQuest program (Becton Dickinson). Two-color cell sorting was performed on a FACSTAR Plus (Becton Dickinson). Populations were $>98 \%$ pure upon reanalysis.

Immunofluorescent labeling of tissue sections. Gut tissues were removed, trimmed of excess fat, and washed extensively in PBS. The tissue was then immersed in Tissue-Tek embedding compound (Miles Scientific, Elkhart, IN) and snap-frozen in liquid nitrogen. Tissue 
blocks were stored at $-70^{\circ} \mathrm{C}$. Sections $(4 \mu \mathrm{m})$ were cut using a ReichertJung Frigocut cryostat (Cambridge Instruments Inc., Buffalo, NY) and immediately air-dried onto glass microscope slides. Tissue sections were simultaneously stained with specific $\mathrm{mAb}$ and anti-cytokeratin using a two-step protocol. Sections were first rinsed in 1\% (vol/ vol) FCS in PBS and then incubated with $30 \mu \mathrm{l}$ of primary mAb (as described above) and rabbit anti-cytokeratin in a humidified staining box for $20 \mathrm{~min}$ at room temperature. Sections were submerged in PBS three times for $5 \mathrm{~min}$ each. Sections were then incubated for 20 min in a mixture of FITC-conjugated goat anti-rat IgG $(\mathrm{H}+\mathrm{L})(8 \mu \mathrm{g} /$ $\mathrm{ml}$; Caltag) and rhodamine-conjugated goat anti-rabbit IgM and IgG $(\mathrm{H}+\mathrm{L})(25 \mu \mathrm{g} / \mathrm{ml}$; Southern Biotechnology Associates Inc., Birmingham, AL) and washed as above. Sections were then mounted in Vectashield Mounting Medium (Vector, Burlingame, CA) under glass coverslips. FITC labeling was detected using a Zeiss Axioskop fluorescence microscope (Zeiss, Germany) set on narrow band blue excitation (440-500 nm), while rhodamine labeling was visualized using narrow band green excitation $(510-565 \mathrm{~nm})$. Photomicrographs were taken using Kodak 1600 ASA professional color print film.

Colon organ culture. Colon organ cultures were prepared from age-matched wt or IL- $10^{-/-}$mice in the following manner. Colons, not including the cecum, were dissected from mice and flushed with cold PBS to remove fecal matter. Each colon was then cut into 2-mm squares, washed in a large volume of PBS plus 5\% FCS and resuspended in RPMI-1640 supplemented with $10 \%$ FCS, $50 \mathrm{mM}$ 2-ME, penicillin $(100 \mathrm{U} / \mathrm{ml})$ and streptomycin $(100 \mathrm{U} / \mathrm{ml})$. Equivalent amounts of tissue were distributed into tissue culture plates (Falcon 3046; Becton Dickinson Labware, Lincoln Park, NJ) containing $5 \mathrm{ml}$ of media alone or media supplemented with LPS $(10 \mu \mathrm{g} / \mathrm{ml})$ or Con A $(5 \mu \mathrm{g} / \mathrm{ml})$. Cultures were incubated at $37^{\circ} \mathrm{C}$ in $5 \% \mathrm{CO}_{2}$. Supernatants were harvested after $48 \mathrm{~h}$ and stored at $-70^{\circ} \mathrm{C}$ until assayed.

T cell culture. Sorted CD4 ${ }^{+}$LPL were cultured in $200 \mu \mathrm{l}$ of RPMI-1640 containing 5\% FCS, 2 mM L-glutamine, 0.05 mM 2-mercaptoethanol and antibiotics in 96-well flat bottomed plates which had been previously coated with $10 \mu \mathrm{g} / \mathrm{ml}$ hamster anti-mouse CD3 $\mathrm{Ab}$ (clone 32C11). Supernatants from duplicate cultures were harvested after $72 \mathrm{~h}$ and stored at $-70^{\circ} \mathrm{C}$ before analysis of cytokine levels by ELISA.

Determination of cytokine and nitric oxide (NO) levels. TNF $\alpha$ and IL-1 $\alpha$ levels in cell supernatants were measured using ELISA kits purchased from Genzyme (Boston, MA) according to the manufacturer's direction. Other cytokine levels were detected by two-site sandwich ELISA assays using $\mathrm{Ab}$ pairs kindly provided by Dr. J. Abrams (DNAX): for IFN $\gamma$, R46A2, and AN18 were used; for IL-6, 32C11 and 20F3; for IL-10, SXC-11, and XT3, and for IL-4, 1D11, and 24G2. NO levels were measured using Griess reagent, as described previously (24).
Peripheral blood analysis. Blood samples from wt and IL-10 ${ }^{-1-}$ mice were obtained via the tail vein. White blood cell counts were determined using a Serono 901 automated counter (Serono Diagnostics, Allentown, PA). Peripheral blood smears were stained with WrightsGiemsa (Sigma Chemical Co., St. Louis, MO). A cell differential was performed to determine the percent of neutrophils and to calculate the absolute number of neutrophils per $\mu$ l of blood. Serum amyloid A (SAA) levels were determined by ELISA using a kit supplied by Biosource (Camarillo, CA) according to the manufacturer's direction.

Treatments with anti-IFN $\gamma$ antibodies or IL-10. Wt and IL-10-1mice received weekly i.p. injections of $2 \mathrm{mg}$ of purified rat antimouse IFN $\gamma \mathrm{mAb}$ (XMG1.2) or isotype-matched anti- $\beta$-galactosidase mAb (GL-117) beginning at $3 \mathrm{wk}$ or 3 mo of age. This amount of anti-IFN $\gamma \mathrm{mAb}$ has been shown to neutralize the activities of endogenously produced IFN $\gamma$ in an animal model of IBD (13). In other experiments, IL-10 $0^{-/-}$mice received daily i.p. injections of IL-10 (2.5, 10 , or $50 \mu \mathrm{g}$ ) or saline beginning at $3 \mathrm{wk}$ and $3 \mathrm{mo}$ of age. Mice were killed after $8 \mathrm{wk}$ of treatment for pathologic evaluation.

Statistical analysis. Significant differences between experimental groups were evaluated by the nonparametric Mann and Whitney U test. A $P<0.05$ was considered statistically significant.

\section{Results}

Characteristics of progressive enterocolitis in aging $I L-10^{-1-}$ mice. A longitudinal study was performed with pathogen-free outbred IL-10 ${ }^{-/-}$mice $(\mathrm{C} 57 \mathrm{BL} / 6 \times 129$ Ola) maintained under clean conditions in order to study the progression of their intestinal disease. Pathologic changes were first seen in 3-wk-old IL-10 ${ }^{-1-}$ mice. These changes consisted of small multifocal infiltrates in the lamina propria of the cecum, ascending and transverse colon and minimal or no epithelial hyperplasia (Fig. $1 \mathrm{~B}$ ). The infiltrates consisted of lymphocytes occasionally accompanied by small numbers of neutrophils. For comparison, a normal colon from a 3-wk-old wt mouse is shown in Fig. $1 \mathrm{~A}$. The mean colonic disease score calculated for the group of 3 wk IL- $10^{-1-}$ mice is shown in Table I. Note that at the time of evaluation only $69 \%$ of the young mutants were showing signs of intestinal disease, which was restricted to the colon. The other $31 \%$ of the mutants were judged as being free of disease based on the normal histological appearance of their intestinal tract and other organs and based on their normal peripheral blood values (see below).

Table I. Longitudinal Study in IL-10 ${ }^{-/-}$Mice

\begin{tabular}{|c|c|c|c|c|c|c|c|}
\hline \multirow[b]{2}{*}{ Age } & \multirow[b]{2}{*}{$n$} & \multirow{2}{*}{$\begin{array}{l}\text { Percent } \\
\text { of mice } \\
\text { affected }\end{array}$} & \multirow{2}{*}{$\begin{array}{c}\text { Colonic } \\
\text { disease score } \\
\text { per group } \\
(0-20)^{\S}\end{array}$} & \multicolumn{2}{|c|}{ Percent of mice with } & \multirow{2}{*}{$\begin{array}{c}\text { Granulocytes } \\
\text { per } \mu \text { l blood } \\
\left(\times 10^{-3}\right)^{\S}\end{array}$} & \multirow{2}{*}{$\begin{array}{l}\text { SAA } \\
\mu \mathrm{g} / \mathrm{ml}^{\S}\end{array}$} \\
\hline & & & & adenocarcinoma & Duodenitis & & \\
\hline \multicolumn{8}{|l|}{ IL10 ${ }^{-1-}$ Mice } \\
\hline $3 \mathrm{wk}$ & 16 & $69 \%$ & $1.5 \pm 0.4 *$ & 0 & 0 & $3.7 \pm 0.6^{*}$ & $138 \pm 29 *$ \\
\hline $3 \mathrm{mo}$ & 12 & $100 \%$ & $6.6 \pm 0.8^{*}$ & $25 \%$ & $8 \%$ & $7.4 \pm 1.0^{*}$ & $617 \pm 46^{*}$ \\
\hline$>6 \mathrm{mo}$ & 10 & $100 \%$ & $10.1 \pm 1.3 *$ & $60 \%$ & $20 \%$ & $10.2 \pm 1.3^{*}$ & $959 \pm 100 *$ \\
\hline \multicolumn{8}{|l|}{ WT Mice } \\
\hline $3 w k$ & 10 & 0 & 0 & 0 & 0 & $1.6 \pm 0.3$ & $47 \pm 8$ \\
\hline $3 \mathrm{mo}$ & 8 & 0 & 0 & 0 & 0 & $1.9 \pm 0.3$ & $39 \pm 6$ \\
\hline$>6 \mathrm{mo}$ & 4 & 0 & 0 & 0 & 0 & $1.9 \pm 0.4$ & $51 \pm 12$ \\
\hline
\end{tabular}

Longitudinal study in IL-10 ${ }^{-1-}$ mice. The entire gastrointestinal tract from mice of different ages was evaluated histologically. $n$ indicates the number of mice per group. ${ }^{\S}$ Data reported as mean \pm SEM per group. ${ }^{\ddagger}$ Duodenitis was mild with a severity score of 1 (see Histologic analysis in results). $* P<0.05$, IL-10 ${ }^{-1-}$ mice vs. age-matched wt mice. 

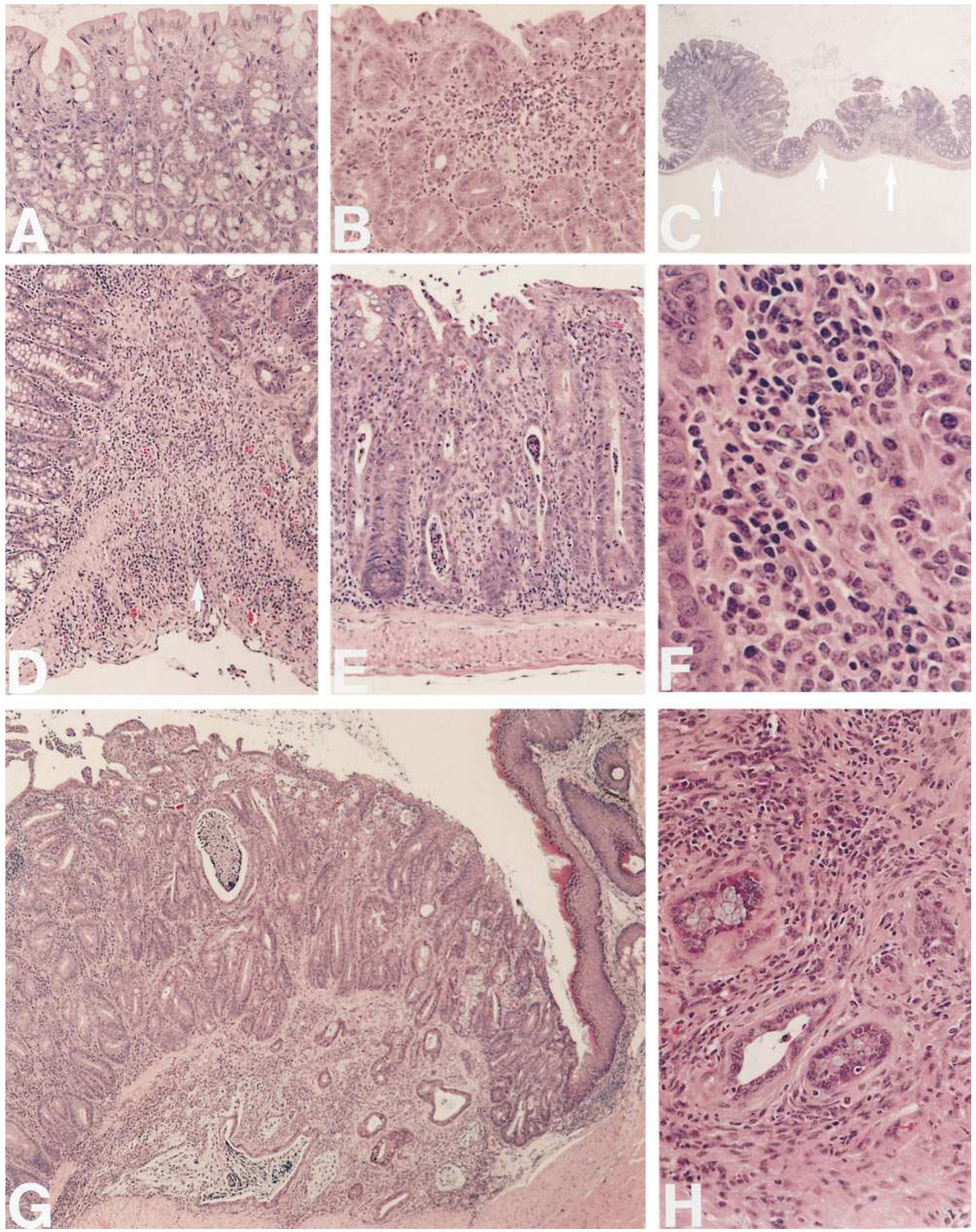

Figure 1. Histopathology of colonic changes in IL-10 ${ }^{-1-}$ mice. (A) Proximal colon from 3-wk-old wt mouse (150×). Note the lack of cellular infiltrate between glands, and the abundance of mucin in goblet cells; $(B)$ Proximal colon from 3-wk-old IL-10 ${ }^{-/-}$mouse $(150 \times)$. There is an accumulation of inflammatory cells in the lamina propria between galnds and mucin depletion from goblet cells; $(C)$ Multifocal inflammation and transmural disease in 3-mo-old IL-10 $10^{-1}$ mouse $(15 \times)$. The tissues at the right and left of the photomicrograph are affected (large arrows) while the tissue in the center is relatively normal (small arrow); $(D)$ Higher magnification $(100 \times)$ of $C$ showing transmural inflammation $($ arrow); $(E)$ Epithelial hyperplasia, inflammation, and crypt abscesses $(140 \times) ;(F)$ Inflammatory infiltrate composed of lymphocytes, macrophages, plasma cells, and a few scattered neutrophils $(440 \times)$. Epithelial cells lining a gland are on the left; $(G)$ Adenocarcinoma in the rectum $(50 \times)$. Note the neoplastic glands in the submucosa. Inflammation and epithelial hyperplasia are present in the mucosa; $(H)$ Higher magnification $(200 \times)$ of an adenocarcinoma from the proximal colon. Several irregular glands lined by well differentiated epithelium are deep in the submucosa. The tunica muscularis is at the bottom. 
By 3 mo of age, multifocal lesions (Fig. $1 C$ ) were seen in the mutants and were often present in all regions of the large intestine from the cecum through the rectum. Epithelial hyperplasia was quite prominent, inflammation was occasionally transmural (Fig. $1 D$ ) and crypt abscesses were sometimes present (Fig. $1 \mathrm{E}$ ). Inflammatory infiltrates were composed predominately of lymphocytes, plasma cells, and macrophages but also contained small-to-moderate numbers of neutrophils and eosinophils (Fig. $1 F$ ). Often the infiltrates were present in both the mucosa and the submucosa. In addition, ulcerations and colorectal adenocarcinoma (Fig. $1, G$ and $H$ ) were observed. The mean colonic disease score of the 3-mo-old IL$10^{-/-}$mice is shown in Table I. At this age, disease was observed in $100 \%$ of the mice and their score was significantly higher $(P<$ 0.001 ) than that of 3-wk-old mutants due to the increased incidence and severity of the lesions. In addition, a small percentage of the 3-mo-old mutants developed duodenitis (Table I).

6-mo-old IL- $10^{-1-}$ mice usually had colonic disease qualitatively similar to but more severe than that seen at 3 mo of age $(P=0.04)$ (Table I). The higher mean disease score observed in the 6-mo-old mutants was due, in part, to the fact that they had more ulcerations and transmural lesions than the 3-mo-old mutants. 6-mo-old IL-10 ${ }^{-1-}$ mice also suffered from a higher incidence of colorectal adenocarcinoma and duodenitis (Table I). No metastases were seen in the mesenteric lymph nodes, liver, or lung. It is not known whether metastases occurred later as a systematic evaluation was not performed for animals older than 6 mo.

Blood granulocytosis and elevated serum amyloid $A(S A A)$ values correlate with disease severity. Blood samples were obtained from wt and IL-10 ${ }^{-1-}$ mice of different ages. It was found that the granulocyte and SAA values were elevated in 3-wk-old IL-10 $0^{-1-}$ mice as compared with age-matched wt mice (Table I). Moreover, these two indicators of inflammation continued to increase in aging mutants and were roughly correlated with the severity of their enterocolitis as determined by histological analyses (Table I). Thus, higher granulocyte and SAA values were detected in 3-mo-old as compared with 3-wk-old IL-10-1mice $(P=0.0006 ; P=0.003)$ and in 6-mo-old as compared with 3-mo-old IL-10 ${ }^{-1-}$ mice $(P=0.03 ; P=0.009)$.

Phenotypic analysis of colonic mononuclear cells. Immunohistologic studies of IL-10 ${ }^{-1-}$ mice confirmed that pathologic changes had occurred as early as $3 \mathrm{wk}$ of age. We found that small groups of epithelial cells in the colon aberrantly expressed MHC class II antigen (Fig. 2, $A$ and $B$ ) and that there were slightly increased numbers of $\mathrm{CD}^{+}$and $\mathrm{CD}^{+} \mathrm{T}$ cells in the lamina propria and minimal to no mucosal hyperplasia (not shown). In contrast, large numbers of epithelial cells throughout the colons of older IL-10 $0^{-1-}$ mice (3-6 mo) expressed MHC class II antigen. Even though there was widespread expression of class II antigen by epithelial cells in these older IL-10 ${ }^{-/-}$ mice (1), mucosal hyperplasia and inflammatory cells were only observed in focal areas. These inflammatory infiltrates contained abnormally high numbers of $\mathrm{F} 4 / 80^{+}$macrophages (Fig. 2, $C$ and $D$ ), CD4 ${ }^{+}$cells (Fig. 2, $E$ and $F$ ) and $C D 8 \alpha^{+}$cells (Fig. 2, $G$ and $H$ ). Elevated numbers of $\mathrm{Ig}^{+} \mathrm{B}$ cells were also noted in the lamina propria of the IL-10 $0^{-1-}$ mice (not shown).

In another set of experiments, colonic $\mathrm{T}$ cells were isolated from the lamina propria of wt and IL- $10^{-1-}$ mice $(3 \mathrm{mo})$ and the proportions of cells expressing CD4 and/or CD8 $\alpha$ were assessed by flow cytometry. In wt mice, the proportion of $\mathrm{CD}^{+}$ versus $\mathrm{CD} 8 \alpha^{+}$cells ranged from 1:2 to 1:3 (Fig. $3 A$ ). The high proportion of $\mathrm{CD} 8 \alpha^{+}$cells detected in the wt mice was unexpected and appears to be due to the influence of the 129-Ola genetic background. We have found that wt mice of the 129 strain consistently show a higher frequency of $\mathrm{CD} 8 \alpha^{+}$as compared with $\mathrm{CD} 4^{+}$LPL (unpublished observation). In contrast to wt mice, the proportion of cells expressing CD4 versus $\mathrm{CD} 8 \alpha$ was consistently reversed in the IL-10 $0^{-1-}$ mice. This finding suggested that the absolute number of $\mathrm{CD} 4^{+} \mathrm{CD} 8 \alpha^{-}$ cells in the mutants was increased (see below). The IL-10 $0^{-/-}$ mice also showed a striking increase in the proportion of $\mathrm{CD} 4{ }^{+} \mathrm{CD} 8 \alpha^{+}$cells. In addition, we found that the majority of $\mathrm{CD} 4^{+}$lymphocytes from the mutants expressed an activated/ memory phenotype as reflected by low levels of CD45RB (Fig. $3 C$ ) (25) and CD62L (Fig. $3 E$ ) molecules and by high levels of the memory/activation markers, CD69 (Fig. 3 D) and CD44 (Fig. $3 F$ ).

On average, $1.7 \pm 0.44\left(\times 10^{6}\right)$ LPL were recovered from the colons of IL- $10^{-1-}$ mice $(n=8)$ as compared with $0.8 \pm 0.3\left(\times 10^{6}\right)$ LPL recovered from the colons of wt mice $(n=6)$. Calculations revealed that relative to wt mice, the absolute number of $\alpha \beta$ TcR CD $4{ }^{+}$and $\mathrm{CD} 4{ }^{+} \mathrm{CD} 8 \alpha^{+}$cells in IL- $10^{-/-}$mice were increased 6- and 30-fold, respectively. However, our in situ immunofluorescence studies suggested that these populations were concentrated more than 50 - to 200 -fold in focal lesions where they may play a pathogenic role. Based on our calculations, it was determined that the colons of $\mathrm{IL}-10^{-/-}$and wt mice contained roughly equivalent numbers of $\mathrm{CD} 4^{-} \mathrm{CD} 8 \alpha^{+}$ cells. This latter finding indicated that the abnormally high number of $\mathrm{CD} 8 \alpha^{+}$cells detected in tissue sections from IL$10^{-1-}$ mice (Fig. 2, $G$ and $H$ ) was due to an absolute increase in $\mathrm{CD} 4{ }^{+} \mathrm{CD} 8 \alpha^{+}$rather than $\mathrm{CD} 4 \mathrm{CD} 8 \alpha^{+} \mathrm{T}$ cells.

Cytokine production by colonic tissue and purified $\mathrm{CD}^{+}$ cells. Tissues from the colons of IL-10 $0^{-1-}$ mice spontaneously produced larger amounts of IL- $1 \alpha$, TNF- $\alpha$, IL- 6 , NO, and IFN- $\gamma$ as compared with wt tissues (Fig. 4). Under these conditions, IL-4 was undetectable. As the colons of IL-10 ${ }^{-1-}$ mice were found to spontaneously produce high levels of IFN- $\gamma$ and to contain increased numbers of $\mathrm{CD}^{+} \mathrm{T}$ cells, we focused on the possibility that an unregulated Th1-type response may contribute to the inflammatory process in this organ. To evaluate this hypothesis, $\mathrm{CD}^{+}$cells purified by $\mathrm{FACS}^{\circledR}$ from the LP of IL-10 $0^{-1-}$ and wt mice were stimulated in culture with antiCD3 antibodies. CD $4^{+} \mathrm{T}$ cells from IL- $10^{-/-}$mice consistently produced large quantities of IFN- $\gamma$ relative to $\mathrm{CD}^{+}$cells from wt mice. (Fig. $5 \mathrm{~A}$ ). In fact, the amount of IFN- $\gamma$ produced by $\mathrm{CD} 4^{+} \mathrm{T}$ cells from wt mice was consistently below the detection level of our assay (Fig. $5 A$, exp. 1). When $\mathrm{CD}^{+} \mathrm{T}$ cells from wt mice were stimulated in the presence of anti-IL-10 $\mathrm{mAb}$, significant levels of IFN- $\gamma$ were produced albeit lower than that produced by $\mathrm{CD} 4^{+} \mathrm{T}$ cells from IL- $10^{-1-}$ mice (Fig. 5 $A$, exp. 2). IFN- $\gamma$ levels remained undetectable in the supernatants of $\mathrm{CD}^{+} \mathrm{T}$ cells from wt mice stimulated in the presence of isotype control mAb (data not shown). The results obtained with wt mice demonstrated that endogenously produced IL-10 was capable of suppressing the in vitro production of IFN- $\gamma$ and thus, it is likely that endogenous IL-10 production mediates a similar affect in vivo when intestinal $\mathrm{T}$ cells encounter enteric antigens. Our experiments also revealed that $\mathrm{CD} 4^{+} \mathrm{T}$ cells from both wt and IL-10 ${ }^{-/-}$mice produced only small amounts of IL-4 (Fig. 5 B). This outcome was consistent with the hypothesis that pathologic changes in the colon of IL-10 ${ }^{-1-}$ mice are due to the unregulated activities of Th1-type cells. 

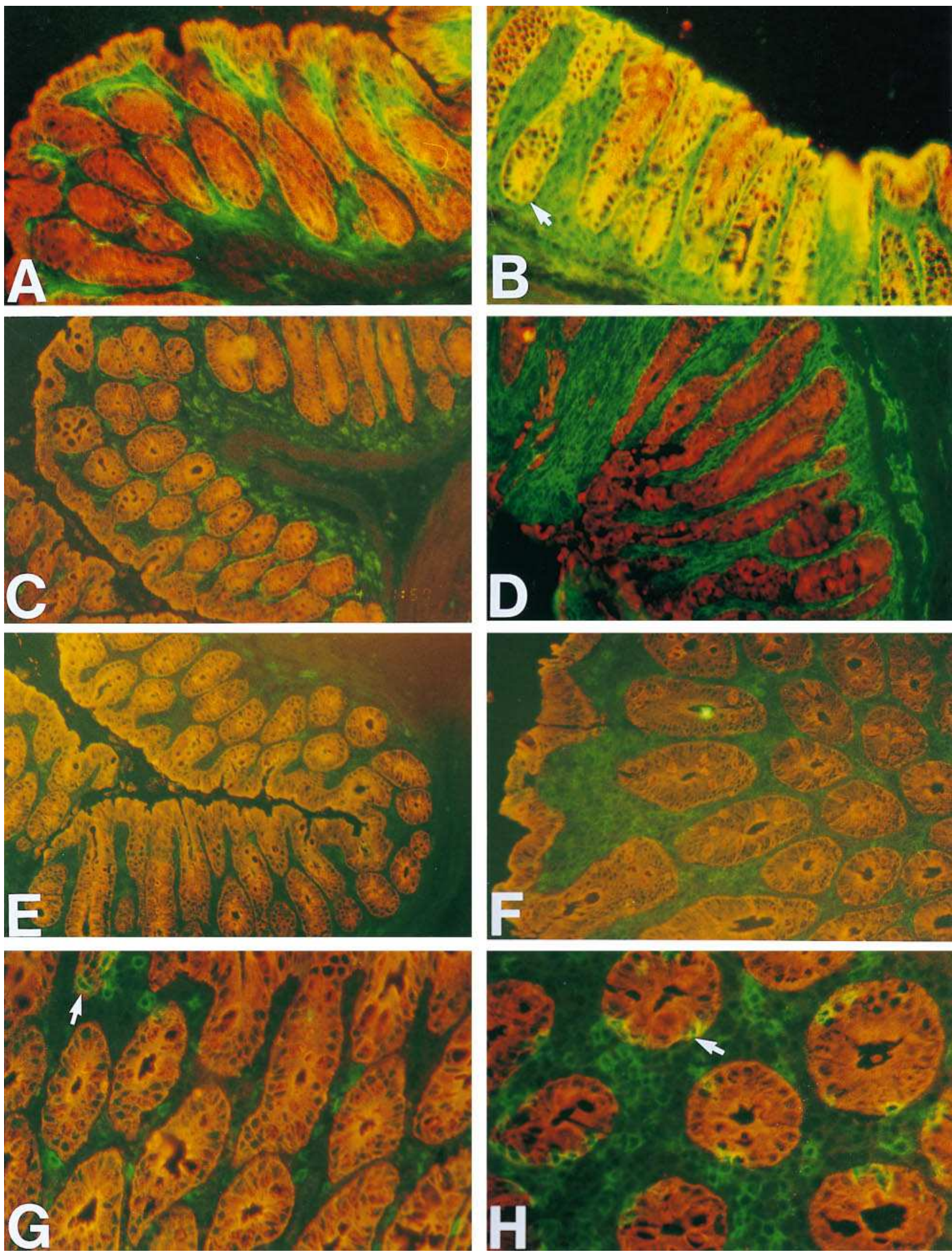

Figure 2. Immunofluorescent staining of frozen colon tissue from wt and IL-10 $0^{-1-}$ mice. Rhodamine (red) labeling of cytokeratin defines epithelial cells. FITC (green) labeling defines specific cell surface markers: $(A)$ MHC class II staining of lamina propria cells of 3 wk wt colon; $(B)$ MHC class II staining of lamina propria cells and epithelial cells in $3 \mathrm{wk} \mathrm{IL-}-10^{-1-}$ colon including surface and crypt (arrow) epithelium where yellow staining indicates co-expression of cytokeratin and MHC class II; $(C) \mathrm{F} 4 / 80^{+}$macrophages in lamina propria of 6 mo wt colon; $(D) \mathrm{F} 4 / 80^{+}$macrophages in

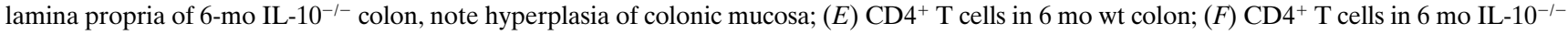
colon, note hyperplasia of colonic mucosa; $(G) \mathrm{CD} 8 \alpha^{+} \mathrm{T}$ cells predominate in epithelial compartment (arrow) of wt colon; and $\mathrm{H}$ ) $\mathrm{CD} 8 \alpha^{+} \mathrm{T}$ cells are increased in both the epithelial compartment (arrow) and the lamina propria of IL-10 ${ }^{-l-}$ colon. $A$ and $B, 200 \times ; C-F, 120 \times ; G$ and $H, 240 \times$. 


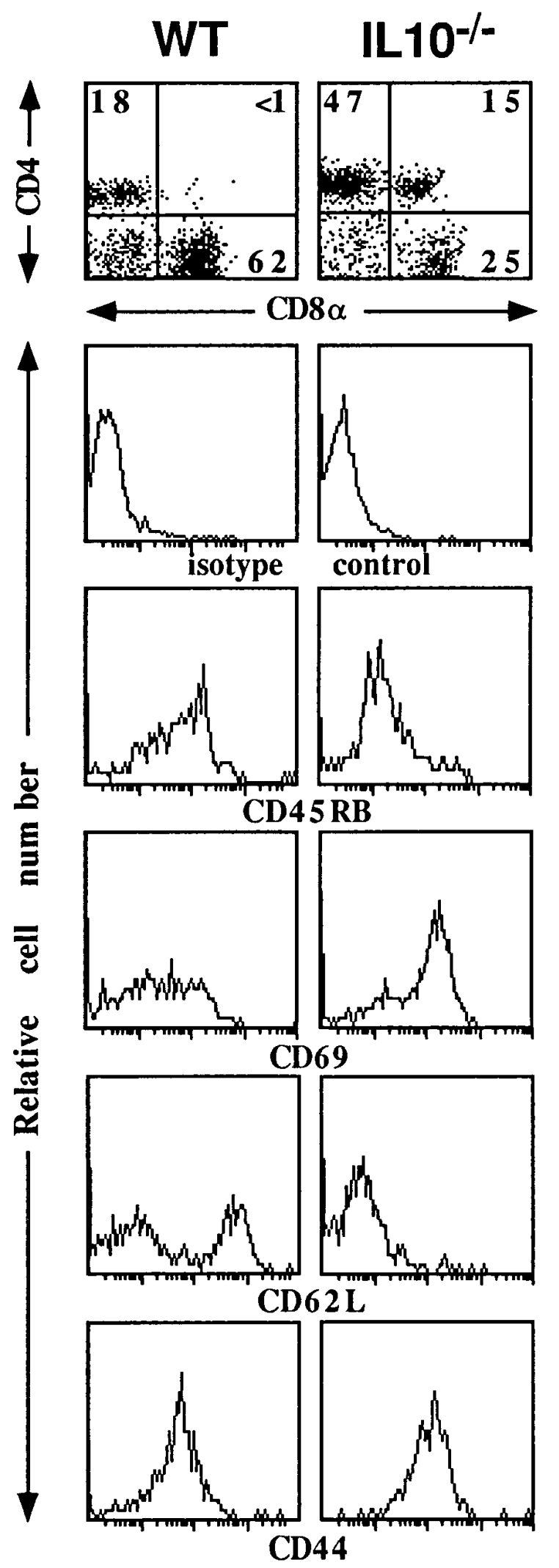

Figure 3. Phenotype of colonic T cells. LPL were isolated from IL-10-1and wt mice and examined by flow cytometry as described in Methods. Profiles are representative of four independent experiments. $(A) \mathrm{CD} 4$ versus CD $8 \alpha$ expression on CD3-gated LPL. The percentage of positive cells is indicated within each quadrant. Expression of various cell surface markers was determined on CD4-gated LPL: $(B)$ isotype control; $(C)$ CD45RB; $(D)$ CD69; (E) CD62L (L-selectin); and (F) CD44 (Pgp-1).
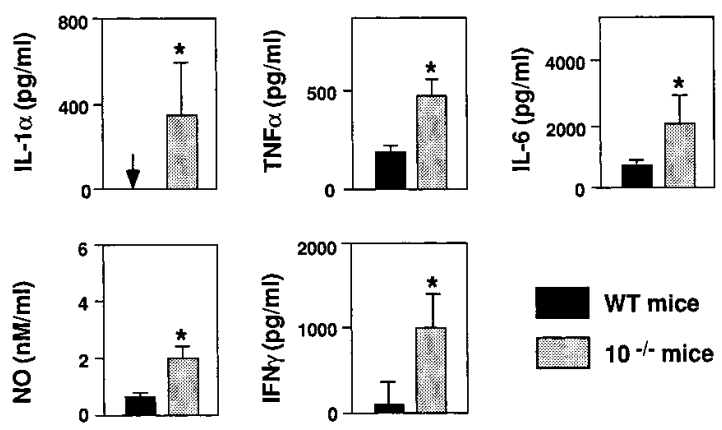

WT mice

$10^{-/-}$mice

Figure 4. Colonic cultures of IL-10 $10^{-/-}$mice produce large amounts of inflammatory mediators. Colon explants from wt or IL-10 ${ }^{-1-}$ mice were cultured in media. Six mice per group were analyzed. Supernatants were harvested after $48 \mathrm{~h}$ of culture and analyzed for cytokine levels by ELISA. Data are representative of two independent experiments. $* P<0.05, \mathrm{IL}-10^{-/-}$mice vs. wt mice.

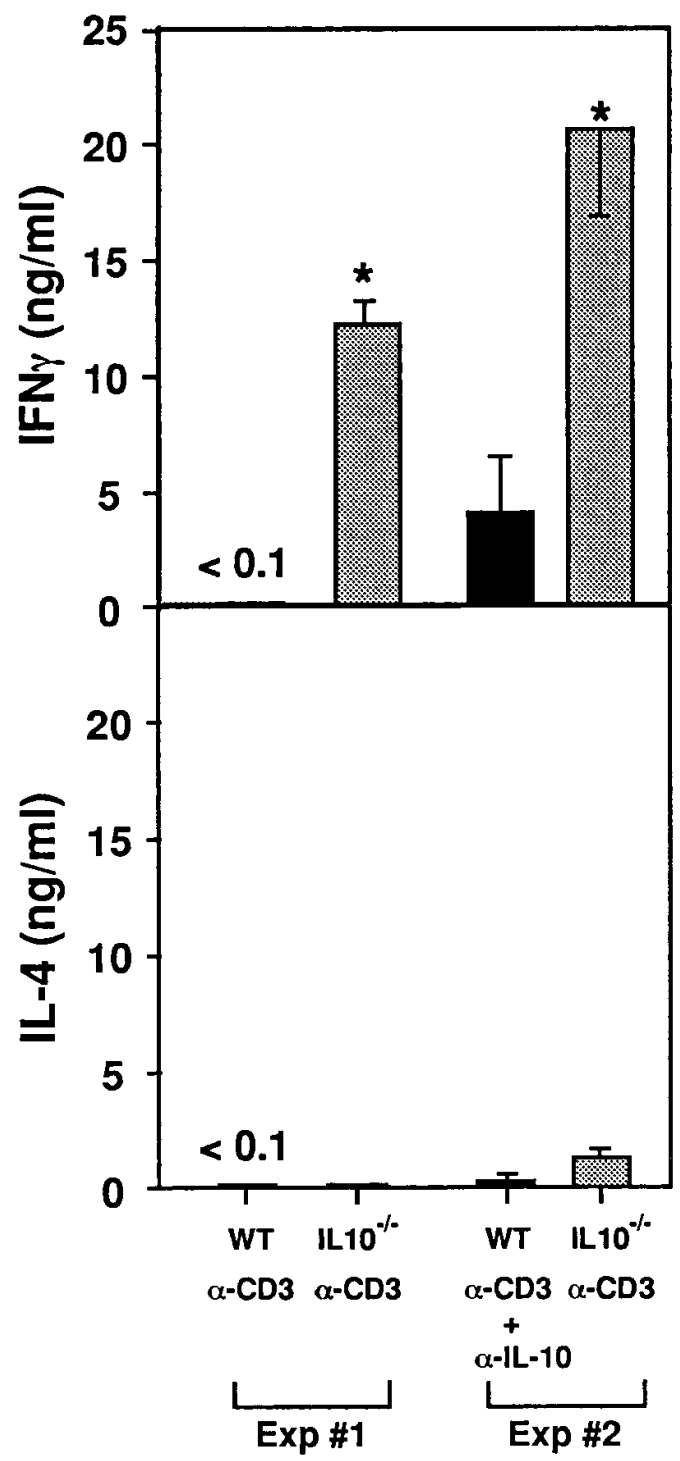

Figure 5. Purified $\mathrm{CD} 4^{+} \mathrm{T}$ cells from the colons of IL-10 ${ }^{-1-}$ mice produce IFN $\gamma$ but little-to-no IL-4. CD4 ${ }^{+} \mathrm{T}$ cells were plated at $3 \times 10^{4}$ cells/well (Exp. 1) or at $2.5 \times 10^{5}$ cells/well (Exp. 2) in anti-CD3 $\mathrm{mAb}$-coated plates as described in Methods. After $48 \mathrm{~h}$ of culture, supernatants were harvested and analyzed for cytokine levels by ELISA. $* P<0.05$, IL- $10^{-1-}$ mice vs. wt mice. 


\begin{tabular}{|c|c|c|c|c|c|c|c|}
\hline \multicolumn{8}{|c|}{ Evaluation of IL-10 $0^{-/-}$mice after $6 \mathrm{wk}$ of treatment } \\
\hline \multirow{2}{*}{$\begin{array}{c}\text { Age } \\
\text { treatment } \\
\text { initiated }\end{array}$} & \multirow[b]{2}{*}{$n$} & \multirow{2}{*}{$\begin{array}{l}\text { Percent } \\
\text { of mice } \\
\text { affected }\end{array}$} & \multirow{2}{*}{$\begin{array}{c}\text { Colonic } \\
\text { disease score } \\
\text { per group } \\
(0-20)^{\S}\end{array}$} & \multicolumn{2}{|c|}{ Percent of mice with } & \multirow{2}{*}{$\begin{array}{l}\text { Granulocytes } \\
\text { per } \mu \text { l blood } \\
\left(\times 10^{-3}\right)^{\S}\end{array}$} & \multirow[b]{2}{*}{$\begin{array}{c}\text { SAA } \\
\mu \mathrm{g} / \mathrm{ml}^{\S}\end{array}$} \\
\hline & & & & $\begin{array}{c}\text { Colorectal } \\
\text { adenocarcinoma }\end{array}$ & Duodenitis $s^{\ddagger}$ & & \\
\hline \multicolumn{8}{|l|}{$3 \mathrm{wk}$} \\
\hline (anti-IFN $\gamma$ mAb) & 16 & $31 \%$ & $1.1 \pm 0.4 *$ & 0 & 0 & $2.1 \pm 0.4^{*}$ & $146 \pm 31 *$ \\
\hline \multicolumn{8}{|l|}{$3 \mathrm{wk}$} \\
\hline (control mAb) & 14 & $93 \%$ & $2.7 \pm 0.5$ & 0 & 0 & $4.6 \pm 0.5$ & $273 \pm 35$ \\
\hline \multicolumn{8}{|l|}{$3 \mathrm{mo}$} \\
\hline$($ anti-IFN $\gamma \mathrm{mAb})$ & 7 & $100 \%$ & $9.5 \pm 0.6$ & $28 \%$ & $57 \%$ & $9.3 \pm 1.2$ & $761 \pm 155$ \\
\hline \multicolumn{8}{|l|}{$3 \mathrm{mo}$} \\
\hline (control mAb) & 12 & $100 \%$ & $9.0 \pm 1.8$ & $25 \%$ & $33 \%$ & $8.6 \pm 1.2$ & $801 \pm 133$ \\
\hline
\end{tabular}

Neutralization of IFN $\gamma$ prevents colitis in young IL-10 $0^{-/-}$mice. IL-10 $0^{-/-}$mice were treated weekly with $2 \mathrm{mg}$ of anti-IFN $\gamma \mathrm{mAb}$. Control mice received weekly treatments with isotype control $\mathrm{mAb}$. After $6 \mathrm{wk}$ of treatment, their intestinal disease was evaluated histologically. $n$ indicates the number of animals per group. ${ }^{\circledR}$ Data reported as mean \pm SEM per group. ${ }^{*}$ Duodenitis was mild with a severity score of 1 (see Histologic analysis in Results). $* P<0.05$, IL- $10^{-1-}$ mice treated with anti-IFN $\gamma \mathrm{mAb}$ vs. control mAb.

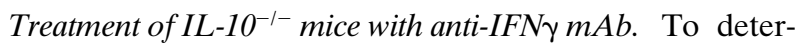
mine the role of IFN $\gamma$ in the development of enterocolitis in IL$10^{-1-}$ mice, neutralizing anti-IFN $\gamma$ or isotype control $\mathrm{mAbs}$ were administered weekly to 3 -wk-old IL- $10^{-1-}$ mice. Immunohistological studies with frozen colon sections revealed that aberrant MHC class II expression on epithelial cells of IL-10 ${ }^{-1-}$ mice was not detectable after six weeks of anti-IFN $\gamma$ mAb treatment. More importantly, 3-wk-old mutants treated for 6 wk with anti-IFN $\gamma \mathrm{mAb}$, but not control mAb, showed a diminished incidence of disease (from 93 to $31 \%$ ) and a reduced mean colonic disease score (Table II). The anti-IFN $\gamma$ treatment also appeared to diminish signs of systemic inflammation as evidenced by their lower blood granulocyte and SAA values when compared with those of mutants treated with control Ab (Table II).

In contrast, when adult IL- $10^{-1-}$ mice ( 3 mo old) were treated with anti-IFN $\gamma \mathrm{mAb}$, the progression of their disease was unaffected (Table II). Nevertheless, MHC class II expres- sion by epithelial cells was abolished. These results suggest that neither IFN $\gamma$ nor MHC class II expression are required for sustaining disease once it has become established.

Treatment of IL-10-1- mice with IL-10. Intraperitoneal injections of IL-10 $(10 \mu \mathrm{g})$ were given daily for $8 \mathrm{wk}$ to IL-10 ${ }^{-/-}$ weanlings ( $3 \mathrm{wk})$ and to diseased adults ( $3 \mathrm{mo})$. IL-10 treatment of weanlings completely prevented the development of enterocolitis (Table III), whereas PBS-treated littermates had lesions typical of mutants approaching the age of 3 mo (refer to Table I). After treating diseased adults with IL-10 for $8 \mathrm{wk}$, we found that they still had enterocolitis (Table III). Although the IL-10-treated adults had a lower mean disease score than that of the PBS-treated controls, the difference was not statistically significant (Table I). Nevertheless, IL-10-treated mice showed no evidence of duodenitis and a reduced incidence of colorectal carcinomas. These results suggested that IL-10 treatment diminished disease progression. In a separate exper-

Table III. Effects of IL-10 Treatment on Enterocolitis in IL-10 ${ }^{-/-}$Mice

\begin{tabular}{|c|c|c|c|c|c|c|c|}
\hline \multicolumn{8}{|c|}{ Evaluation of IL- $10^{-/-}$mice after $8 \mathrm{wk}$ of therapy } \\
\hline \multirow{2}{*}{$\begin{array}{c}\text { Age } \\
\text { treatment } \\
\text { initiated }\end{array}$} & \multirow[b]{2}{*}{$n$} & \multirow{2}{*}{$\begin{array}{l}\text { Percent } \\
\text { of mice } \\
\text { affected }\end{array}$} & \multirow{2}{*}{$\begin{array}{c}\text { Colonic } \\
\text { disease score } \\
\text { per group } \\
(0-20)^{\S}\end{array}$} & \multicolumn{2}{|c|}{ Percent of mice with } & \multirow{2}{*}{$\begin{array}{c}\text { Granulocytes } \\
\text { per } \mu 1 \text { blood } \\
\left(\times 10^{-3}\right)^{8}\end{array}$} & \multirow[b]{2}{*}{$\begin{array}{l}\mathrm{SAA} \\
\mu \mathrm{g} / \mathrm{ml}^{\S}\end{array}$} \\
\hline & & & & $\begin{array}{c}\text { Colorectal } \\
\text { adenocarcinoma }\end{array}$ & Duodenitis & & \\
\hline \multicolumn{8}{|l|}{$3 \mathrm{wk}$} \\
\hline (IL-10) & 6 & $17 \%$ & $0.2 \pm 0.2 *$ & 0 & 0 & $1.7 \pm 0.2 *$ & $93 \pm 24 *$ \\
\hline \multicolumn{8}{|l|}{$3 \mathrm{wk}$} \\
\hline (PBS) & 5 & $100 \%$ & $6.8 \pm 1.4$ & 0 & 0 & $7.2 \pm 1.4$ & $497 \pm 126$ \\
\hline \multicolumn{8}{|l|}{$3 \mathrm{mo}$} \\
\hline (IL-10) & 7 & $100 \%$ & $5.3 \pm 1.3$ & $28 \%$ & 0 & $6.8 \pm 1.0$ & $745 \pm 144$ \\
\hline \multicolumn{8}{|l|}{$3 \mathrm{mo}$} \\
\hline (PBS) & 6 & $100 \%$ & $10.0 \pm 1.9$ & $67 \%$ & $33 \%$ & $9.1 \pm 1.4$ & $1,025 \pm 180$ \\
\hline
\end{tabular}

Effects of IL-10 treatment on enterocolitis in IL-10 $0^{-/-}$mice. IL-10 $0^{-/-}$mice were given daily i.p. injections of IL-10 (10 $\left.\mu \mathrm{g}\right)$ or PBS. After 8 wk of treatment, their intestinal disease was evaluated histologically. $n$ indicates the number of animals per group. ${ }^{\circledR}$ Data reported as mean \pm SEM per group. ${ }^{\ddagger}$ Duodenitis was mild with a severity score of 1 (see Histologic Analysis in Results). $* P<0.05$, IL-10 ${ }^{-1}$ mice treated with IL-10 vs. PBS. 
Table IV. Effects of Genetic Background on the Development of Enterocolitis in IL-10-/- Mice

\begin{tabular}{|c|c|c|c|c|c|c|c|}
\hline \multirow{2}{*}{$\begin{array}{c}\text { Genetic } \\
\text { background }\end{array}$} & \multirow[b]{2}{*}{$n$} & \multirow{2}{*}{$\begin{array}{c}\text { Percent } \\
\text { of mice affected }\end{array}$} & \multirow{2}{*}{$\begin{array}{c}\text { Colonic } \\
\text { disease score } \\
\text { per group } \\
(0-20)^{\S}\end{array}$} & \multicolumn{2}{|c|}{ Percent of mice with } & \multirow{2}{*}{$\begin{array}{l}\text { Granulocytes } \\
\text { per } \mu 1 \text { blood } \\
\left(\times 10^{-3}\right)^{8}\end{array}$} & \multirow{2}{*}{$\begin{array}{c}\mathrm{SAA} \\
\mu \mathrm{g} / \mathrm{ml}^{\S}\end{array}$} \\
\hline & & & & adenocarcinoma & Duodenitis & & \\
\hline $\mathrm{IL} 0^{-/-} \mathrm{C} 57 \mathrm{BL} / 6$ & 7 & $57 \%$ & $2.9 \pm 1.1^{*}$ & $0 \%$ & 0 & $3.4 \pm 0.4 *$ & $226 \pm 66^{*}$ \\
\hline $\mathrm{IL}_{10}^{-/-} \mathrm{BALB} / \mathrm{c}$ & 7 & $100 \%$ & $8.6 \pm 1.2 *$ & $29 \%$ & 0 & $8.0 \pm 1.6^{*}$ & $519 \pm 62 *$ \\
\hline IL10 ${ }^{-l-} 129 \mathrm{SvEv}$ & 9 & $100 \%$ & $11.2 \pm 1.4^{*}$ & $67 \%$ & 0 & $9.8 \pm 2.1^{*}$ & $1,132 \pm 263^{*}$ \\
\hline C57BL/6 & 4 & 0 & 0 & 0 & 0 & $1.1 \pm 0.1$ & $54 \pm 12$ \\
\hline $\mathrm{BALB} / \mathrm{c}$ & 4 & 0 & 0 & 0 & 0 & $2.1 \pm 0.1$ & $37 \pm 10$ \\
\hline $129 \mathrm{SvEv}$ & 4 & 0 & 0 & 0 & 0 & $2.1 \pm 0.3$ & $21 \pm 3$ \\
\hline
\end{tabular}

Effects of genetic background on the development of enterocolitis in IL-10 ${ }^{-/-}$mice. IL-10 $0^{-1-}$ mice backcrossed onto C57B1/6J, 129/SvEv, and BALB/c backgrounds were evaluated for enterocolitis at 3 mo of age. $n$ indicates the number of animals per group. ${ }^{8}$ Data reported as mean \pm SEM per group. ${ }^{\ddagger}$ Duodenitis was mild with a severity score of 1 (see Histologic Analysis in results). ${ }^{*} P<0.05$, IL- $10^{-l-}$ mice vs age-matched wt mice.

iment, 2.5 or $50 \mu \mathrm{g}$ of IL-10 were administered daily to diseased adults. The lower dose had marginal or no effect (data not shown). Treatment with the highest dose was discontinued because it produced adverse side affects (i.e., malaise and loss of appetite).

Genetic background influences the severity of enterocolitis in $I L-10^{-1-}$ mice. The contribution of heritable factors to the development of intestinal inflammation was evaluated by backcrossing the IL-10 gene mutation onto C57BL/6J, 129/ $\mathrm{SvEv}$ and BALB/c genetic backgrounds. The resulting inbred strains were evaluated at 3 mo of age, a time when $100 \%$ of the IL-10 ${ }^{-1-}$ outbred mice (C57BL/6 × 129/Ola) developed intestinal inflammation. Comparisons of 3-mo-old IL-10-1- C57BL/6 mice with other IL-10 ${ }^{-1-}$ strains (Table IV) and outbred mice (Table I) indicated that the C57BL/6 mutants were relatively resistant to colitis. In contrast, the disease in 3-mo-old IL-10 ${ }^{-1-}$ $129 / \mathrm{SvEv}$ mice was exacerbated as compared with agematched IL-10 ${ }^{-1-}$ outbred mice (Table I). In fact, their disease resembled that displayed by 6 -mo-old IL- $10^{-1-}$ outbred mice except for the absence of duodenitis (Table I). Interestingly, the IL-10 ${ }^{-1-}$ BALB/c strain had a high incidence of lesions similar to the IL-10 ${ }^{-/-} 129 / \mathrm{SvEv}$ mice although they had fewer carcinomas (Table IV).

\section{Discussion}

We have characterized the natural progression of enterocolitis in pathogen-free IL-10 $0^{-1-}$ mice and evaluated the genetic and immunologic components which may be responsible for the disease process. With respect to disease progression, our studies have determined that inflammatory lesions in young IL$10^{-1-}$ mice begin as small focal areas of inflammation and minimal epithelial hyperplasia in the cecum, ascending colon, and transverse colon. These early lesions contained increased numbers of $\mathrm{T}$ cells and epithelial cells aberrantly expressing $\mathrm{MHC}$ class II molecules. Interestingly, pathologic changes first observed in 3-wk weanlings occurred at an age when significant colonization of the gastrointestinal tract with normal flora takes place (26). Furthermore, the regions where the lesions were present in young IL-10 ${ }^{-1-}$ mice are known to be colonized with the greatest number and types of bacteria (26). A more severe form of disease was observed in 3-mo-old adults in which multifocal lesions were present in multiple segments of the colon and occasionally in the duodenum. Ultimately, progressive disease in aging IL- $10^{-1-}$ mice was characterized by an increased number of focal ulcerations and transmural lesions. Although these features are reminiscent of those manifested by human patients with Crohn's disease $(15,16)$, IL$10^{-1-}$ mice also exhibited features atypical of Crohn's disease. These include marked crypt hyperplasia, the rare occurrence of granulomas, fibrosis and lymphoid aggregates, and the absence of fissures, fistulae, and ileal inflammation. Therefore, IL- $10^{-1-}$ mice cannot be viewed as a true model of Crohn's disease.

A significant finding in 6-mo-old IL-10-1- mice was epithelial hyperplasia. It was not clear whether the hyperplasia developed at the same time as the inflammation. In some cases intestinal glands, lined by hyperplastic cells and sometimes filled with mucus, extended into the underlying submucosa and occasionally to the serosa. These changes were considered to represent a non-neoplastic finding consistent with colitis cystica profunda (27-30). Other lesions were characterized by more irregular glands, back-to-back growth of glands, small nests of epithelial cells in the intestinal wall, fibrosis, and slight loss of nuclear polarity. These lesions were considered to represent adenocarcinomas similar to those described in $\mathrm{G \alpha}_{\mathrm{i} 2}$-deficient mice (9). It is recognized that the only unequivocal criterion for malignancy is metastasis (31), and none was observed in the IL- $10^{-1-}$ mice or in the $\mathrm{G} \alpha_{\mathrm{i} 2}$ mice. A high incidence of adenocarcinoma has been observed in the colons of human patients suffering from prolonged IBD $(15,16,32,33)$. It is not clear whether these rodent models will be useful in studying the mechanism(s) responsible for intestinal carcinomas associated with human IBD.

Ethnic and familial studies in humans have suggested that certain individuals are genetically predisposed to develop IBD $(34,35)$. However, these types of studies have faltered because they failed to demonstrate a simple type of inheritance due to a dominant or recessive gene. New rodent models of spontaneous intestinal disease offer exciting opportunities to define modifier genes that determine increased disease susceptibility or resistance. Our studies have shown that enterocolitis occurred earlier and was more severe in IL- $10^{-/-}$mice with the $129 / \mathrm{SvEv}$ background as compared with the original IL-10 ${ }^{-/-}$ outbreds $\left(129 /\right.$ Ola $\times$ C57BL/6). The IL-10 ${ }^{-1-}$ C57BL/6 strain was least affected. Similarly, colitis in TcR $\alpha$ chain-deficient mice ( $\mathrm{TcR} \alpha^{-1-}$ ) was more severe in the $129 \mathrm{~Sv}$ strain than in outbred mice $(129 / \mathrm{Sv} \times \mathrm{C} 57 \mathrm{BL} / 6)(8)$. In both models of dis- 
ease, it appears that the 129 genetic background conferred disease susceptibility while the C57BL/6 genetic background conferred resistance. Interestingly, TcR $\alpha^{-l-} 129 / \mathrm{Sv} \times \mathrm{BALB} / \mathrm{c}$ (F2) mice also developed a diminished form of colitis as compared with $\mathrm{TcR} \alpha^{-1-} 129 / \mathrm{Sv}$ mice (8). This finding suggested that BALB/c, like C57BL/6, is a non-permissive background for $\mathrm{TcR} \alpha$-deficient mice. Unfortunately, identical backcrosses have not been made with IL-10 $0^{-/-}$mice so direct comparisons are not possible. Nevertheless, our studies have shown that $\mathrm{BALB} / \mathrm{c}$, in contrast to $\mathrm{C} 57 \mathrm{BL} / 6$, is a permissive background for the development of enterocolitis in IL- $10^{-/-}$mice. A tentative conclusion is that different but overlapping subsets of genetic loci govern the distinct forms of enterocolitis observed in $\mathrm{TcR} \alpha^{-1-}$ and IL-10 $0^{-1-}$ mice. Hopefully, genetic mapping studies with these and other rodent models of intestinal disease (36) will identify the common and unique regulatory genes that determine disease susceptibility and will ultimately permit the identification of corresponding genes involved in the heterogeneous forms of human IBD.

A major aim of our study was to investigate the mechanism(s) responsible for enterocolitis in IL- $10^{-1-}$ mice. We found that intestinal tissue from diseased IL- $10^{-/-}$mice spontaneously produced in vitro exaggerated amounts of cytokines relative to that of wt tissue. The finding that IL- $1 \alpha$, TNF, IL-6, and NO levels were elevated and that F4/80 staining cells were present in very high numbers implied uncontrolled cytokine production by macrophages contributed to the pathogenic response. Abnormally high numbers of $\alpha \beta \mathrm{TcR}^{+} \mathrm{CD}^{+}$and $\mathrm{CD} 4{ }^{+} \mathrm{CD} 8 \alpha^{+} \mathrm{T}$ cells were also detected in the colonic lesions. These $\mathrm{CD}^{+}$cells were capable of producing large amounts of IFN $\gamma$ and little-to-no IL-4, typical of Th1 T cells (37). The possibility that the unregulated activities of macrophages and Th1 cells play a causal role in the disease was not unexpected as in vitro studies have shown that IL-10 is a potent inhibitor of cytokine production by these cell types (2-5). Theoretically, IFN $\gamma$ could mediate many deleterious effects such as altering gut physiology and decreasing epithelial barrier function (38$40)$. In addition, the ability of IFN $\gamma$ to heighten cytokine production by macrophages (41) exposed to luminal bacterial products would further amplify the inflammatory response (40), particularly in the absence of negative regulation by IL-10.

A pathogenic role for IFN $\gamma$-producing cells in the development of enterocolitis by IL- $10^{-1-}$ mice was confirmed by infusion studies with neutralizing anti-IFN $\gamma$ mAb. When IL-10 ${ }^{-/-}$ weanlings were treated with anti-IFN $\gamma \mathrm{mAb}$ for $6 \mathrm{wk}$, a smaller proportion (31\%) developed colitis as compared with weanlings treated with control mAb (93\%). Although antiIFN $\gamma$ treatment had a beneficial effect, it did not prevent disease in $100 \%$ of the recipients. Therefore, it is likely that the actions of other inflammatory mediators such as TNF, IL-1, IL-6, and/or NO also contribute to the induction of disease in IL-10 ${ }^{-1-}$ mutants. These pro-inflammatory mediators have been linked to IBD in humans (42-45) and to colitis in several animal models $(13,46)$. In contrast to the results obtained with IL-10 ${ }^{-1-}$ weanlings, established colitis in adult mutants was unaltered by $6 \mathrm{wk}$ of treatment with anti-IFN $\gamma$ mAb. However, it was demonstrated that aberrant Class II antigen expression was eliminated on the colonic epithelial cells of the treated adults. Although incomplete neutralization of IFNy could account for the failure of the treatment to reverse established disease, it is also likely that while IFN $\gamma$ may be instrumental in initiating a pathogenic response, it is not required for its con- tinuation. Additional immune defects, aside from unregulated IFN $\gamma$ production, must develop in IL- $10^{-1-}$ mice and help perpetuate intestinal inflammation.

Finally, our studies have shown that two months of IL-10 therapy was very effective in modulating intestinal disease in young IL- $10^{-1-}$ mice. Mutants treated daily with IL-10 from 3 wk of age remained free of disease. The absence of any pathologic changes suggested that IL-10 suppressed the generation and activities of Th1-like $\mathrm{T}$ cells and other immunopathogenic cells such as macrophages. Recently, it was reported that IL-10 administration prevented the induction of colitis in $63 \%$ of scid mice transplanted with $\mathrm{CD}_{45 \mathrm{RB}^{\text {hi }}} \mathrm{CD}^{+} \mathrm{T}$ cells whereas, colitis occurred in $100 \%$ of transplant recipients treated with PBS (13). Striking similarities between this model of colitis and IL-10 ${ }^{-1-}$ mice include a pathogenic role for IFN $\gamma$ and the presence of predominantly mononuclear infiltrates with transmural lesions. Presently, it is not known if IL-10 can prevent colitis in other animal models of enterocolitis (8-11) where pathogenic mechanisms appear to differ from those identified for transplanted scid mice (13) and IL-10 $0^{-1-}$ mice.

Infusion of adult IL-10 ${ }^{-1-}$ mice with IL-10 for 2 mo did not cure their colitis. Because IL-10 therapy did not reverse established disease in adults but prevented the development of colitis in weanlings, it is likely that IL-10 plays a key role early in the immune response by inhibiting the generation of pathogenic effector cells. Despite the failure of IL-10 therapy to cure established disease, it reduced the incidence of adenocarcinomas and duodenitis associated with progressive disease. One way in which IL-10 therapy may impede pathological changes once effector cells have been generated is by simply controlling their production of inflammatory mediators. Relevant to this point, it has been reported that IL-10 enemas administered to IBD patients for $10 \mathrm{~d}$ resulted in diminished cytokine production and improved histological scores (47). Future studies with IL-10 $10^{-/-}$mice and other animal models of intestinal disease will undoubtedly lead to a clearer understanding of the entire pathogenic process and improve chances of developing effective treatments for human IBD.

\section{Acknowledgments}

The authors gratefully acknowledge the expert technical assistance of Ms. Hartman and the staff of the Histology Laboratory at the Schering-Plough Research Institute, especially Mr. J. Syed. We also thank Ms. Routhier for assistance in preparation of the manuscript.

DNAX Research Institute of Molecular and Cellular Biology is supported by Schering-Plough Corporation.

\section{References}

1. Kühn, R., J. Löhler, D. Rennick, K. Rajewsky, and W. Müller. 1993. Interleukin-10-deficient mice develop chronic enterocolitis. Cell. 75:263-274.

2. Moore, K.W., A. O'Garra, R. de Waal Malefyt, P. Vieira, and T.R. Mosmann. 1993. Interleukin-10. Annu. Rev. Immunol. 11:165-190.

3. de Waal-Malefyt, R., J. Abrams, B. Bennett, C.G. Figdor, and J. de Vries. 1991. Interleukin 10 (IL-10) inhibits cytokine synthesis by human monocytes: an autoregulatory role of IL-10 produced by monocytes. J. Exp. Med. 174:1209-1220.

4. Fiorentino, D.F., A. Zlotnik, T.R. Mosmann, M. Howard, and A. O'Garra. 1991. IL-10 inhibits cytokine production by activated macrophages. $J$. Immunol. 147:3815-3822.

5. Fiorentino, D.F., M.W. Bond, and T.R. Mosmann. 1989. Two types of mouse T helper cell. IV. Th2 clones secrete a factor that inhibits cytokine production by Th1 clones. J. Exp. Med. 170:2081-2095.

6. Berg, D.J., R. Kühn, K. Rajewsky, W. Müller, S. Menon, N. Davidson, G. Grünig, and D. Rennick. 1995. Interleukin-10 is a central regulator of the response to LPS in murine models of endotoxic shock and the Shwartzman reac- 
tion but not endotoxin tolerance. J. Clin. Invest. 96:2339-2347.

7. Berg, D.J., M.W. Leach, R. Kühn, K. Rajewsky, W. Müller, N.J. Davidson, and D. Rennick. 1995. Interleukin-10 but not interleukin 4 is a natural suppressant of cutaneous inflammatory responses. J. Exp. Med. 182:99-108.

8. Mombaerts, P., E. Mizoguhi, M.J. Grusby, L.H. Glimcher, A.K. Bhan, and S. Tonegawa. 1993. Spontaneous development of inflammatory bowel disease in T cell receptor mutant mice. Cell. 75:274-282.

9. Rudolph, U., M.J. Finegold, S.S. Rich, G.R. Harriman, Y. Srinivasan, P. Brabet, G. Boulay, A. Bradley, and L. Birnbaumer. 1995. Ulcerative colitis and adenocarcinoma of the colon in $\mathrm{G} \alpha_{\mathrm{i} 2}$-deficient mice. Nat. Genetics 10:143-149.

10. Shull, M.M., I. Ormsby, A.B. Kier, S. Pawloski, R.J. Diebold, M. Yin, R. Allen, C. Sidman, G. Proetzel, D. Calvin, N. Annunziata, and T. Doetschman. 1992. Targeted disruption of the mouse transforming growth factor- $\beta 1$ gene results in multifocal inflammatory disease. Nature (Lond.). 359:693-699.

11. Sadlack, B., H. Merz, H. Schorle, A. Schimpl, A.C. Feller, and I. Horak. 1993. Ulcerative colitis-like disease in mice with a disrupted interleukin-2 gene. Cell. 75:253-261.

12. Holländer, G.A., S.J. Simpson, E. Mizoguchi, A. Nichogiannopoulou, J. She, J-C. Gutierrez-Ramos, A.K. Bhan, S.J. Burakoff, B. Wang, and C. Terhorst. 1995. Severe colitis in mice with aberrant thymic selection. Immunity. 3:27-38.

13. Powrie, F., M.W. Leach, S. Mauze, S. Menon, L. Barcomb-Caddle, and R.L. Coffman. 1994. Inhibition of Th1 responses prevents inflammatory bowel disease in scid mice reconstituted with CD45RB ${ }^{\text {hi }} \mathrm{CD}^{+} \mathrm{T}$ cells. Immunity. 1:553-562.

14. Morrissey, P.J., K. Charrier, S. Braddy, D. Liggitt, and J.D. Watson. 1993. CD4 ${ }^{+} \mathrm{T}$ cells that express high levels of CD45RB induce wasting disease when transferred into congenic severe combine immunodeficiency mice. Disease development is prevented by cotransfer of purified $\mathrm{CD}^{+}{ }^{+} \mathrm{T}$ cells. J. Exp. Med. 178:237-244.

15. Lewin, K.J., Riddell, R.H., and W.M. Weinstein. 1992. Inflammatory Bowel Disease. Gastrointestinal Pathology and Its Clinical Implications. IgakuShoin, New York. 812-989.

16. Podolsky, D.K. 1991. Inflammatory bowel disease I. N. Engl. J. Med. 325:928-937.

17. Lowes, J.R., and D.P. Jewell 1990. The immunology of inflammatory bowel disease. Springer Sem. Immunopathol. 12:251-268.

18. Sartor, R.B. Cytokines in intestinal inflammation: pathophysiological and clinical considerations. 1994. Gastroenterol. 106:533-539.

19. MacDonald, T.T. and J. Spencer. 1988. Evidence that activated mucosal $\mathrm{T}$ cells play a role in the pathogenesis of enteropathy in human small intestine. J. Exp. Med. 167:1341-1349.

20. Podolsky, D.K. 1991. Inflammatory bowel disease II. N. Engl. J. Med. 325:1008-1016.

21. Sartor, R.B. 1992. Role of the intestinal microflora in pathogenesis and complications. In Inflammatory Bowel Diseases: Pathophysiology as Basis of Treatment. J. Scholmerich, H. Goebell, W. Druis, and W. Hohenberger, editors. Kluwer Academic Publishers, London. 175-187.

22. Ho, A., Y. Liu, T.A. Khan, D. Hsu, J.F. Bazan, and K.W. Moore. 1993. A receptor for interleukin-10 is related to interferon receptors. Proc. Natl. Acad. Sci. USA 90:11267-11271.

23. Lefrançois, L. 1993. Isolation of mouse small intestine intraepithelial lymphocytes. In Current Protocols in Immunology. Vol. 1. J.E. Coligan, A.M. Kruisbeek, O.H. Margulies, E.M. Shevach and W. Strober, editors. John Wiley and Sons, Inc., New York. 3.19.1-3.19.7.

24. Boudard, F., N. Vallot, C. Cabaner, and M. Bastide. 1994. Chemiluminescence and nitrite determinations by the MALU macrophage cell line. J. Immunol. Meth. 174:259-268.

25. Lee, W.T., X.M. Yin, and E.S. Vitetta. 1990. Functional and ontogenetic analysis of murine CD45R ${ }^{\text {hi }}$ and CD45R ${ }^{\text {lo }} \mathrm{CD}^{+}{ }^{+}$T cells. J. Immunol. 144:32883295 .

26. Schaedler, R.W., R. Dubos, and R. Costello. 1965. The development of the bacterial flora in the gastrointestinal tract of mice. J. Exp. Med. 122:59-66.

27. Brynjolfsson, G., and L.S. Lombard. 1993. Colitis cystica in mice. Can- cer. 23:225-229.

28. Boothe, A.D., and N.F. Cheville. 1967. The pathology of proliferative ileitis of the golden Syrian hamster. Path. Vet. 4:31-44.

29. Epstein, S.E., W.Q. Ascari, R.C. Ablow, W. Seaman, and R. Lattes 1966. Colitis cystica profunda. Am. J. Clin. Path. 45:186-201.

30. Wayte, D.M., and E.B. Helwig. 1967. Colitis cystica profunda. Am. J. Clin. Path. 48:159-169.

31. Rowlatt, C., and F.C. Chesterman. 1979. Tumours of the intestines and peritoneum. In Pathology of Tumours in Laboratory Animals. V.S. Turusov, editor. International Agency for Research on Cancer, Lyon. 169-191.

32. Korelitz, B.I. 1990. Considerations of surveillance, dysplasia, carcinoma of the colon in the management of ulcerative colitis and Crohn's disease. Med. Clin. North. Am. 74:189-199.

33. Petras, R.E., J.H. Mir-Madjlessi, and R.G. Farmer. 1987. Crohn's disease and intestinal carcinoma. A report of ll cases with emphasis on associated dysplasia. Gastroenterol. 93:1307-1314.

34. Orholm, M., P. Mukholm, E. Langholz, O.H. Nielsen, T.I.A. Sorensen, and V. Binder. 1991. Familial occurrence of inflammatory bowel disease. $N$. Engl. J. Med. 324:84-88.

35. Yang, H., T. Shohat, and J.I. Rotter. 1992. The genetics of inflammatory bowel disease. In Current Topics of Gastroenterology. R.P. MacDermott, W.F Stenson, editors. Elsevier. pp. 17-51.

36. Sundberg, J.P., C.O. Elson, H. Bedigian, and E.H. Birkenmeier. 1994. Spontaneous, heritable colitis in a new substrain of $\mathrm{C} 3 \mathrm{H} / \mathrm{HeJ}$ mice. Gastroenterol. 107:1726-1735.

37. Cherwinski, J.M., J.H. Schumacher, K.D. Brown, and T.R. Mosmann. 1987. Two types of mouse helper T cell clone. III. Further differences in lymphokine synthesis between Th1 and Th2 clones revealed by RNA hybridization, functionally monospecific bioassays, and monoclonal antibodies. J. Exp. Med. 166:1229-1244.

38. Colgan, S.P., C.A. Parkos, C. Delp, M.A. Arnaout, and J.L. Madara 1993. Neutrophil migration across cultured intestinal epithelial monolayers is modulated by epithelial exposure to IFN gamma in a highly polarized fashion. J. Cell Biol. 120:785-798.

39. Madara, J.L., and J. Stafford. 1989. Interferon-gamma directly affects barrier function of cultured intestinal epithelial monolayers. J. Clin. Invest. 83: 724-727.

40. Beagley, K.W., and C.O. Elson. 1992. Cells and cytokines in mucosal immunity and inflammation. Gastroenterol. Clin. North. Am. 21:347-366.

41. Trinchieri, G., and B. Perrussia. 1985. Immune interferon: a pleiotropic lymphokine with multiple effects. Immunol. Today. 6:131-136.

42. Ligumsky, M., P.L. Simon, F. Karmeil, and D. Rachmilewitz. 1990. Role of interleukin 1 in inflammatory bowel disease-enhanced production during active disease. Gut. 31:686-689.

43. Mahida, Y.R., K. Wu, and D. Jewell. Enhanced production of interleukin $1-\beta$ by mononuclear cells isolated from mucosa with active ulcerative colitis or Crohn's disease. Gut. 30:835-838.

44. MacDonald, T.T., P. Hutchings, M.Y. Choy, S. Murch, and A. Cooke. 1990. Tumour necrosis factor-alpha and interferon-gamma production measured at the single cell level in normal and inflamed human intestine. Clin. Exp. Immunol. 81:301-305.

45. Reinecker, H.-C., M. Steffen, T. Witthoeft, I. Pflueger, S. Schreiber, R.P. MacDermott, and A. Raedler. 1993. Enhanced secretion of tumor necrosis factor-alpha, IL-6, IL-1 beta by isolated lamina propria mononuclear cells from patients with ulcerative colitis and Crohn's disease. Clin. Exp. Immunol. 94:174-181.

46. Cominelli, F., C.C. Nast, and B.D. Clark. 1990. Interleukin 1 (IL-1) gene expression, synthesis and effect of specific IL-1 receptor blockade in rabbit immune complex colitis. J. Clin. Invest. 86:927-980.

47. Schreiber, S., T. Heinig, H.-G. Thiele, and A. Raedler. 1995. Immunoregulatory role of interleukin 10 in inflammatory bowel disease in vitro and in vivo. Gastroenterol. 108:1434-1444. 